\title{
Francis, Thou Art Translated: Petrarch Metamorphosed in English, 1380-1595
}

\author{
Ronald L. Martinez, Brown University
}

\begin{abstract}
English translation of Petrarch-translation that is also metamorphosis in a manner that Petrarch would have recognized-begins with Chaucer's rendition of $R v f 132$ as the canticus Troili in the first book of Troilus and Criseyde, an inaugural moment of lyric imitation long thought unique in Chaucer's work. Yet suggestive claims have been made that $R v f 189$ was also rendered by Chaucer as Troilus' second canticus in book V, within a context inclusive of additional Petrarchan influences on Chaucer. Chaucer's versions, and their contextualization in the Troilus, had definite consequences for Petrarchan translation when it resumed with the Henrician poets Thomas Wyatt and Henry Howard a century and a half later. For the Tudor poets living under the tyranny of Henry VIII the Petrarch-inspired sonnet offered a richly articulated space of private reflection that did not fail to register the pressure of court politics. Wyatt's Petrarchan translations in the Egerton manuscript represent a privileged part of his lyric production, a preference that the Earl of Surrey absorbed for his very different poetic program, one designed to exalt both aristocratic lineage and an aureate genealogy of poets including Virgil, Dante, and Chaucer along with Petrarch and Wyatt. Mediated by multiple editions of Tottel's Songs and Sonnettes between 1557 and 1594, the legacy of Wyatt's and Surrey's Petrarchan translations reached the Elizabethans with an emphasis on Petrarch's poetic supremacy that stimulated emulation by the young Shakespeare. His tragedy Romeo and Juliet threw down a challenge to Petrarch with respect to sonnet forms, sonnet rhetoric, and the typical story of enamorment, a story still discernibly affiliated with Chaucer's Troilus.
\end{abstract}

"And I exhort the unlearned, by reding to learne to bee more skillful, and to purge that swinelike grossenesse, that maketh the swete majerome not to smell to their delight.” (Richard Tottel, “To the reder,” 1557)

“"Assist me, some extemporal god of rime, for I am sure I shall turn sonnet. Devise, wit; write, pen; for I am for whole volumes in folio.”, (William Shakespeare, Love’s Labors Lost, I.ii.105-106)

My title alludes, with an apotropaic nod to Bottom's appearance in Shakespeare's Midsummer Night's Dream, to translation as metamorphosis. Or perhaps rather to metamorphosis as a way of speaking about translation, specifically Tudor translation of 
Petrarch into English as a principal agent for "purging that swinelike grossenesse" Tottel deplores (a counsel that could fairly be directed at Bottom himself). The book that the Tudor poets reckoned with, Petrarch's Rerum vulgarium fragmenta (hereafter Rvf), though titled after its formal dispersiveness, is indebted for thematic coherence to the idea of metamorphosis: Laura's image is constantly metamorphosed in the speaker's memory and his passion subjects him to metamorphosis; most important, the poetry itself results from metamorphosis. As Robert Durling remarked, there are some transformations in "Nel dolce tempo de la prima etade" ( $R v f 23)$ that are figures of sublimation, while some suggest that poetry is an expression for emotions otherwise blocked by sexual fear (Petrarca Lyric, 2229). Petrarch offers an etiology of poetry as the therapeutic discharge in language of repressed desire (23.4: "perché cantando il duol si disacerba”): as a translation of desire, in other words. Indeed, explicitly so in a scene representing internal experience transmuted into language, the speaker of the canzone, his voice silenced by Laura's interdict, cries out his self-alienation through ink and paper: "gridai con carta e con incostro: / non son mio, no..." (23.99-100; see Barkan 211). The cry was destined to resonate as "I am not myne, I am not myne" in an anonymous translation of the canzone, published in Richard Tottel's influential anthology of 1557 (no. 154.154; see also no. 206), and would be reiterated in various guises by English Petrarchan personae such as Sidney's Astrophil (Astrophel no. 45.14: "I am not I: pity the tale of me") and Shakespeare's Romeo (Romeo and Juliet [Rom.]: I.i 196-97 "Tut, I have lost myself; I am not here / This is not Romeo, he's some other where"). ${ }^{1}$

In a more prosaic sense Petrarch's vernacular poetry, which harvests rich traditions of Latin and Romance lyric, is always already translation, if not always as transparently as in the case of $R v f 145$, "Ponmi ove'l sole occide i fiori e l'erba" a consistent imitation of Horace's Carmen I.22.17-24, with a conclusion that alludes to Propertius. In a letter to Boccaccio, relying on Senecan precedents, Petrarch himself described his preferred practice of creative imitation through the analogy of the son's resemblance to his father, to suggest how a new work might resemble but differ from its original (Fam. 23.19.11-12; see Pigman; Greene, "Petrarch"; Rossiter 21-22). Like Boccaccio and Dante, Petrarch, despite his excursion into direct translation in the case of Boccaccio's Tale of Griselda, eschewed and probably disdained the serviceable form of translation known as volgarizzamento, aiming instead at a transformative art of imitation. ${ }^{2}$ His most talented imitators followed his example: it has been observed of Wyatt's translations of the psalms that "the translator at once pays homage to the original text and transforms it into the representation of his own voice and culture" (Greenblatt 120).

The instances discussed in this essay are a minute sampling of the reception of Petrarch's poetry in Renaissance English letters and exemplify only a few of the ways Petrarch's texts are translated so as to generate new works. Chaucer incorporated Petrarchan lyric into the narrative development of Troilus and Criseyde. Thomas Wyatt and Henry Howard, Earl of Surrey, adopt the voice of the Petrarchan subject and a form-the "pretty roome" of the sonnet, in John Donne's phrase, or "small parcells" in Tottel's-where a politically resistant kind of writing and self-fashioning finds shelter (Greenblatt 155-56, 
Foley 37). For these two poets the Petrarchan sonnet "creates a tiny private space in which, while bewailing its own powerlessness, the speaking voice can assert its superiority of judgment and feeling, its integrity, or at least its ironic self-knowledge in a faithless and unsympathetic world" (Heale 105). For Shakespeare, Petrarch the laureate poet furnishes both mythologized characters and rhetorical devices for The Most Excellent and Lamentable Tragedie of Romeo, and Iuliet. As it happens, these three moments of Petrarchan influence display a suggestive coherence and continuity.

In this metamorphic context even what appears to be close translation, such as "Set me wheras the sonne dothe perch the grene" (Howard no. 3), a version, atypically faithful for Surrey, of $R v f 145$-Petrarch's version, as we saw, of lines from a Horatian ode-is rather a carefully calibrated imitative gesture in which the poem's theme of fidelity resonates metapoetically with the fact of translation itself. In transforming his classical models, Petrarch's poem enumerates twenty-six conditions. These are deployed in lines 1-4 as oppositions expressed by pairs of verses, in lines 5-8 as pairs of opposed conditions divided by caesurae, and in lines 9-11 in groups of three and even four per verse: only in the last line does the poem regain a verse-filling phrase. Petrarch's poem, in effect a highly organized list, was doubtless congenial to the additive, paratactic style Surrey adopted in his sonnets (Thomson 201-203, Zitner 523, Ferry 79, Heale 90-91), for Surrey follows Petrarch's articulation closely and adopts Petrarch's anaphora on "Ponmi" for the quatrains and tercets with his own "Set me" for all but the last three lines, where a departure is required by the final couplet. George Puttenham, in his Arte of English Poesy (published 1589) cited Surrey's version for its use of anaphora and quoted it as an example of the "distributor" [merismus], a strategy of amplification for orators. The rhetorical elaboration is necessary, however, for Surrey's poem begins as a lover's boast but ends as a promise of faith, "a mnemonic epigram equal to a vow." As William Sessions observes, "Surrey enacts an objective and historically liturgical performance. A great deal of the text appears, in fact, to be a reinscription of the exchange of wedding vows, pronounced in 1532, the year of Surrey's wedding, in English in the middle of a Latin ceremony" (201). In this context, even Propertius's Latin (Elegiae 2.15.36: "huius ero vivus, mortuus huius ero"), reminiscent of the Roman legal formula of exchange that stands behind Petrarch's penultimate line ("sarò qual fui, vivrò com'io son visso"), proves functional in underwriting the transformation of the Italian poem into an English liturgical act, "the original epigrammatic drive of the sonnet becoming ceremonious language” (Sessions 200). Surrey's claim of fidelity, at once personal affirmation and historical document, is also metapoetically "faithful": cognizant of the Latin sources transferred into Petrarch's vernacular, Surrey makes his translation of Petrarch's Italian the pledge of a literary constancy and continuity worthy of the "courtly maker," the humanist and laureate poet that Surrey aspired to be.

\section{Petrarch in Troilus and Criseyde}

Early studies by E.H. Wilkins and Patricia Thomson emphasized the supposed mistakes and padding of Chaucer's translation of the fourteen lines of $R v f 132$, "S'amor non è," into twenty-one lines of rhyme royal in the Troilus (I.400-421). Thomson acknowledges that the 
canticus "anticipates future developments in the hero's personality" and that the sonnet "does make its own contribution to Troilus and Criseyde" but her treatment tends to minimize Petrarch's impact on the narrative text, and thus on Chaucer in general (Thomson 164-65). I will rather proceed with the assumption, which I borrow from several recent critics, that to consider the lyric in its context explains Chaucer's choices as translator better than taking the stanzas in isolation. In short, we are dealing not with volgarizzamento, but imitation, and with a long and ambitious poem demonstrably articulated as a dialectic of lyric and narrative modes (Boitani, Tragic 56-74; Rossiter 109-31).

Thus for each stanza of his translation, Chaucer adopts different expedients. In the first line, Chaucer notoriously takes the first line to mean "If no such thing as love exists" rather than-as Petrarch's line is usually understood-that love is the cause of what he feels ("S' amor non è, che dunque è quel ch'io sento?”). But Chaucer's version is in fact consistent with traditional poetic renderings in Italian of the scholastic quaestio regarding the existence and nature of love, and it is thus both conceivable and defensible that his translation is a willful departure from the received interpretation. ${ }^{3}$ The first four lines of the stanza mirror the first four of Petrarch's quatrain, but after the fourth Chaucer inserts an additional three lines, not found in Petrarch, which frame Troilus's desire in terms at once sensual (Love's adversities are "savory") and suggestive of an unslakable spiritual thirst (V.406: "For ay thurst I, the more that ich it drynke"), or perhaps a parody of such a thirst, thus glossing Troilus's besotted idolatry of Criseide. ${ }^{4}$ The second stanza is the least altered: Chaucer retains Petrarch's quatrain topics in order, filling out the rhyme royal stanza with one added line in the middle (410: "I noot, ne whi unwery that I feynte"). In the third stanza Chaucer follows Petrarch's continuation of the argument regarding the lover's consent from the second quatrain into the sestet (lines 8-9: “...s'io nol consento? / E s'io 'l consento...”). But by end-stopping the topic that runs over into the midst of the stanza's second line and by inserting the logical connective "thus," with no counterpart in Petrarch (414-15: “...I wrongfully / Compleyne, iwis. Thus passed to and fro"), Chaucer spotlights the turn to the nautical metaphor and to Troilus's state of being "Amydde the see, bitwixen wyndes two" (417). Troilus's fluctuation summarizes the to and fro of the debate undertaken in the previous stanzas: an effect more marked in Chaucer's version than in Petrarch's, further enhanced by the insertion of a medical metaphor opening the final couplet (419: "Allas, what is this wondre maladye?"). The language of disease gives a new and serious context to the Petrarchan antitheses of heat and cold, which for Chaucer have the power to bring about Troilus's death (line 420), and the medical metaphor also ties the three stanzas together by resuming the interrogative mood of the first stanza. Justified, too, in retrospect, are the thirsting and drinking images of the first stanza, now appearing medicalized as symptoms of lovesickness, aegritudo amoris (Thomson 161; Boitani, Tragic 72; Rossiter 125-26). As we will see in a moment, Chaucer's focus on the nautical and medical metaphors also prepares later developments.

Chaucer's translation of Petrarch's sonnet, sometimes known as the Canticus Troili, although it has always been admired, has also long been thought an isolated incident (Thompson 165; Boitani 5): at once the sole textual trace of Petrarch's vernacular lyric 
production in Chaucer's work and the only translation of Petrarch until the Tudor versions of Wyatt, Surrey, and anonymous others. But Tom Stillinger has ably defended the claim that the other song of Troilus (also designated in some manuscripts as a canticus Troili), in the fifth book (V.596-601), should be thought of as inspired by another sonnet by Petrarch, $R v f 189$ ("Passa la nave mia colma d'oblio"), though it is far from a direct translation. Stillinger's analysis proposes that the non-linear, not to say scrambled, representation of Petrarch's original be taken as symptoms of Troilus's psychic disintegration and of a strategic crisis of representation in the Troilus in general (Stillinger 165-72, 183-89, 194-95, 204-205). What is of interest to my subject here, however, is the fertile premise of Stillinger's argument: that Chaucer knew not an isolated sonnet of Petrarch, but a version of the Canzoniere-perhaps a manuscript of the Chigi version, since Chaucer's text of $R v f 132$ reports the correct reading of the poem according to the Chigi version (Wilkins 169). As Stillinger argues, Chaucer, while in Italy in 1368, $1372-73$ or 1378, was more likely to have encountered a manuscript of the Chigi or later version than to have happened upon isolated poems or fascicles (172-78). What is more, since the Chigi concludes the first part of Petrarch's collection with Rvf 189 (Petrarca, Canz. 820), that poem may have been conspicuous to Chaucer's view. It is also clear that $R v f 132$ and 189 are themselves closely related verbally: although the nautical metaphor is frequent in Petrarch's collection (e.g. Rvf 80, 132.10-12, 235.5-14, 366.67-71), in the case of these two poems the parallels are multiple and coordinated, as Diani has exhaustively tabulated (157). The second text often referred to as canticus Troili is as follows:

O sterre, of which I lost have al the light,

With herte soor wel oughte I to biwaille,

That evere derk in torment, nyght by nyght,

Toward my deth, with wynd in steere I saille;

For which the tenthe nyght, if that I faille

The gydyng of thi bemes bright an houre,

My ship and me Caribdis will devoure. (TCV.596-601)

The contrasts between the polished account of $R v f 132$, which celebrates Troilus's longdelayed surrender to Love by embellishing its source (perhaps to suggest how Troilus's heart expands in love), and the disordered, diminished version of $R v f 189$, marking the beginning of the end for Troilus's affair with Criseyde, are strongly motivated thematically: if the first sonnet requires amplificatio to fill three stanzas, the second canticus is literally a half-sonnet, articulated within a single stanza of rhyme royal as a single quatrain and single tercet. Chaucer's sequence of topics inverts Petrarch's, who mentions the obscuration of the lady's eyes at the end of the sonnet, while for Chaucer this event is placed first; but Petrarch names Scylla and Charybdis early, while in Chaucer Charybdis is mentioned in the last line, as the fatal destination. Petrarch's sonnet is thus upended: the tormented logic of the fragment results in part from this inversion. The topsy-turvy sonnet mirrors Troilus's disintegrating confidence in the prospects for his love: thus the "word is cosyn to the dede" (Canterbury Tales I.742). 
The beginning and end of the fragment also register strong Chaucerian modifications with respect to $R v f 189$. Although the "dolci usati segni," of $R v f 189$ stand for Laura's eyes, Chaucer's placement of "O sterres" to begin the canticus distances him from Petrarch, who never begins a poem in $R v f$ addressing his lady's eyes, and the fragment ends with "devour," never found in Petrarch's lyrics. For a parallel we must go to Dante's Inferno, where this term describes how the bottom of Hell swallows its damned ("al fondo che divora / Lucifero con Giuda” Inf. 31.142). This last Chaucerian modification exceeds Petrarch's tempered lyric diction to reflect the gravity of Troilus's condition within the narrative: indeed, Troilus "at sea" evokes Dante's Ulysses, swallowed up by the ocean and found in Hell. Again, Troilus's narrative situation conditions the lyric text, or, if we accept Picone's reading of Petrarch's sonnet, supplements it by realizing the narrative implications of $R v f 189$, which for Picone alludes to the disaster of Dante's Ulysses (Picone 170-76).

Thus as Stillinger observes, even if we were to reject Chaucer's direct knowledge of $R v f$ 189, we would still have a second Troilian canticus that is unmistakably a development of the first canticus, where the third stanza contains the same Petrarchan topos, as we saw, suitably emphasized in order to enter into dialogue with the canticus in the final book. The narrative consequence of the close relation of the two cantici is to juxtapose in the reader's mind the scene of Troilus's enamorment, which occurs before the first canticus, and the moment that heralds his ruin.

This plurality of lyrics is itself significant in Chaucer's poem, which, as readers have pointed out, is a translation of Boccaccio's Filostrato, where lyric insets are seamlessly fitted into the narrative texture (Stillinger 179-89; see also Natali). The presence of the narrator's Boethian hymn ( TC III.1-49), and Troilus's own lyric apostrophe to Love, near the center of the work (III.1254-74), and Pandarus's canzone-like apostrophe of Love in III.1743-1771, again in Boethian terms, suggests that Troilus, too, is a lyric "anthology" including poems ranging from love lyrics and canzoni to a philosophical hymn; nor is this an exhaustive list.

Indeed Chaucer, after inserting Troilus's first song where there is none in Boccaccio, replaces a discrete lyric when he finds one in the Filostrato (V.62). The text he replaces is Boccaccio's version of a five-stanza canzone by Cino da Pistoia, "La dolce vista e'l bel guardo soave," which Boccaccio digests into four stanzas of otta va rima (he omits the third), after which he adds a further stanza of his own devising, consistent in theme with Cino's canzone (Boccaccio 217, 330). The canzone is further a model for Chaucer in that Boccaccio must adapt the canzone stanza to the narrative octave, an exercise that requires the solution of problems similar to those Chaucer faces accommodating Petrarch's sonnet to the rhyme royal stanza of Troilus. ${ }^{5}$ We cannot be sure that Chaucer knew the authorship of Cino's canzone inserted by Boccaccio, ${ }^{6}$ but we can conclude that he recognized it as a distinct lyric, since he replaced it with a distinct canticus of his own. If, moreover, we take the two cantici Troili as a system, the fact that Chaucer inserted as the first canticus a poem by an author different from that of his proclaimed source (the enigmatic Lollius) may suggest he was aware that the Cino insertion was by an author different from the author of Filostrato. Chaucer may thus have been cognizant of participating in a multiauthorial system of transferring, deleting, and inserting poems, an activity not unlike Petrarch's in compiling 
the Rvf. Indeed, Chaucer calls special attention to the insertion of the first canticus by insisting that he goes beyond his immediate source in giving "naught only the sentence / As writ myn auctor called Lollius," but the whole text, and further warrants that the reader (or copyist) will find that full text immediately following: "and whoso list it here, / Loo, next this vers he may it fynden here" (I.398-99). He thus announces the prestige of the original, as well as foregrounding his active collection and compilation of texts.

For my purposes it is significant that lyric patches are especially abundant in the same regions of the poem as the Petrarchan borrowings, though only in Chaucer, as we saw, are both of Troilus's lyric moments marked with the insert of a canticus. Troilus's first canticus, for example, comes immediately before his formal submission to the god of Love, three stanzas that seem like another song, and that in some manuscripts were in fact conflated with the Petrarchan material; moreover, the first stanza of Chaucer's version subsequently circulated separately (Chaucer 1028, Stillinger 251). The context of the second canticus Troili is even richer in lyric insets: Troilus V.561-81 recalls, distributed in seven clauses beginning with yonder, the places of Troilus's meetings with Criseyde, including his first sight of her: "And in that temple, with hire eyen cleere, Me kaughte first my righte lady dere" (566-67); and his winning of her: "in that yonder place / My lady me first took unto hire grace" (580-81). The equivalent passage in Boccaccio's poem is coordinated with five anaphoric iterations of quivi and four of colà (Fil. V.54-55), a passage that scholars have long noted is closely related to Petrarch's $R v f 112$, a sonnet to Sennuccio del Bene that recalls Laura "qui tutta umile, et qui la vidi altera" and so on, with ten iterations (Petrarca, Canz. 520-21). If Chaucer had a complete Petrarch he might have noted the resemblances with Boccaccio's narrative. It may thus be significant that although both Petrarch and Chaucer recall Laura and Criseyde singing ( $R v f$ 112.9: "Qui cantò dolcemente”; Troilus V.577-78: "so woomanly, with voice melodyous / syngen so weel”), Boccaccio’s Troilo does not so recall his lady.

Beyond these multiple lyric moments leading up to the second canticus, which consist of a typically Petrarchan act of recollecting the lady (562: “And every thyng com hym to remembrance") we can consider the immediate framing of the song. Troilus is "between hope and drede" (630) just before beginning his song as Boccaccio's Troilo is not, but as Petrarch's speaker definitely is in $R v f 134.2$ : "et temo e spero, e ardo, e son un giaccio / in questo stato son, donna, per voi." 7 Troilus wishes "his woful herte for to lighte" (634), where Boccaccio has "alcuna sosta quasi al dolor dando" (Fil. V.61.4)—not as close as $R v f$ 293.10: "pur di disfogare il doloroso core," from the sonnet that begins the in morte portion of the Chigi version, and that echoes, from the canzone of metamorphoses, Petrarch's familiar assertion of what motivates his song, "perché cantando il duol si disacerba" ( $R v f$ 23.4). After his song, Troilus remarks of the air that drifts from the Greek camp that "or is eyr, that is so soote / that in my soule I fele it doth me boote" possibly recalling $R v f 109.12$ 13: "quasi un spirto gentil di paradiso / sempre in quell'aere par che mi conforte." Boccaccio mentions the breath of wind, but not the air: "ciò che soffiarsi sentia del viso, / sì come mandati sospiri da Criseida" (Fil. V.70.4-6). Considering that Petrarch's sestet to the same sonnet begins with "L'aura soave che dal chiaro viso / move col suon de le parole 
accorte...” it might be asked if Chaucer's eyr echoes l'aura, one of the homonyms for Laura in the $R v f$ and thus an intimately Petrarchan signature. In this context and spirit one also wonders if the line in Boccaccio's author's preface, "E voi, amanti, priego ch'ascoltiate..." (Fil. I.6.1), imitates the first lines of $R v f 1$ or instead suggested Petrarch's opening to him (and a common source, such as Lam. 1.12, cannot be excluded; see Martinez 1-10). And of course Troilus is surprised by love in a "temple," the narrative situation that Petrarch stages in poems 2-3 of $R v f$. a scene already topical with Dante in the Vita nuova and that after Boccaccio and Petrarch becomes a commonplace, not to say a banality in narratives of courtly love (Chaucer 1027, Thomson 164-65).

The many parallels between Filostrato and $R v f$, and the direction of the influence, are aspects of a longstanding debate that cannot be settled here, although the current trend seems to be in favor of Boccaccio's precedence more often than not. ${ }^{8}$ David Wallace suggests that the winds tugging at Troilus at the heart of his first canticus represent Chaucer's two Italian masters Boccaccio and Petrarch, which makes of Chaucer's sonnet the earliest contested ground of the debate itself (63). Whichever way the influence went, far more than the textual traces of $R v f 132$ and 189 in Troilus exist to suggest that Chaucer framed his story in a broadly Petrarchan context and that he enjoyed more than anecdotal access to some form of $R v f$. Looking to the future, Chaucer's example generated a substantial literary corpus based on the amorous Troilus and sparked a pair of Tudor versions of $R v f 132$ and, in light of Stillinger's claims, may also have inspired versions of $R v f 189$, notably Wyatt's "My galy charged with forgetfulnes" but also several attempts by Thomas Lodge and an important adaptation by Shakespeare in Romeo and Juliet.

\section{Trial by Sonnet: Wyatt and Surrey}

Recent studies of the poets of the Henrician era have emphasized that under the violently imposed reforms of Henry VIII, in a period of shifting loyalties, reversals of fortune, and catastrophic consequences to imprudent speech, Thomas Wyatt and Henry Howard, Earl of Surrey, developed forms of writing that were not merely constative of royal glory or offered as counsel to the King, in the tradition of the Mirror of Princes, but instead explored an "inward language” in Anne Ferry's phrase: what Greg Walker has called “writing under tyranny” (Walker 299-334, Sessions 143-318, 352-420). In Wyatt's case, his writing was abstracted from, though always in relation to, the royal focus of power. For Surrey, writing fostered an aristocratic cultural prestige independent of, even antagonistic to, the king's: a strategy that was to prove fatal. For these two poets, the Petrarchan persona of the $R v f$-hopeful but abashed, narcissistic, reticent and secretive in the public eye, but anxious, passionate, even tumultuous in his internal life, and consequently both internally conflicted and sharply aware of his difference from the world around him-was highly suitable. The Petrarchan persona served whether the conflicts the poets expressed were internal struggles with shifting desires or vulnerabilities to external events and restraints on behavior; it served whether the dangers of the outside world were erotic, or political-in the case of Wyatt's relationship to Anne Boleyn, mistress and the queen of Henry VIII, the likely subject of a number of poems, necessarily both. ${ }^{9}$ 
The high-water mark of direct Tudor Petrarchan translation, and a chief literary monument of the Henrician period (though first published in 1557, during the last months of the reign of Catholic Mary Tudor), where the bulk of Wyatt and Surrey's translations and imitations of Petrarch are included (Parker 1939), is Tottels's Songs and Sonnettes. Modern students of the work discern a Petrarchizing tendency in the editor's titling of a wide variety of poems as reflecting the predicaments of an afflicted lover, even when the content of the poems is evidently political, and this occultation explains in part why considerable recent study of both Wyatt and Surrey has been devoted to filling in the implicit political tensions behind the poetry. ${ }^{10}$ Through Tottel's popularizing anthology the idea of Petrarch as the supreme lyric poet reached Elizabethans like Sidney and Shakespeare.

In Wyatt's particular case, a collection of his poetry, the Egerton manuscript, unbound in Wyatt's lifetime but consisting of leaves that likely retained their order, reveals his own hand at work in the copying and revision of many of his poems. ${ }^{11}$ The majority of the poems are fairly copied into the manuscript by an amanuensis; many of the poems (some 59) were approved by Wyatt himself (Harrier i-xiii; Powell 261-64). The placement among the first 32 poems of 16 sonnets or other poems translated or imitated from Petrarch gives a clear indication of the high importance Wyatt attributed to the difficult exercise of Petrarchan imitation. A return to Petrarchan exemplars at the end of the portion of the manuscript given to Wyatt's shorter poems (folios 67r-70r, including Wyatt's version of $R v f 360$ in poulter's meter, with corrections in his handwriting, and the opening two lines of $R v f 129$, in his handwriting), though perhaps merely fortuitous, may imply Wyatt's decision to frame the collection of shorter lyrics with Petrarch-inspired compositions (Collected Poems [hereafter M\&T] 79-82, 84).

Most interesting for my purposes, the Egerton manuscript begins with a rondel (rondeau) based on Petrarch's madrigal $R v f 121$ ("Or vedi, Amor") and offers in third position a sonnet closely imitated from Petrarch, Rvf 102, “Cesare, poi che'l traditor d'Egitto" (M\&T, no. 3). With regard to the political inflection of courtly life under Henry VIII, Wyatt's translation, "Caesar when the traytour of Egypt," closely follows Petrarch's humanist parable, one that well-informed readers might have seen flavored with Machiavellism: with an explicit invocation of bookish lore ("si come è scritto," Wyatt's "as it is writt"), the historical examples of Caesar and Hannibal occupy the quatrains, as if miniature Plutarchan parallel lives. The pair is in multiple chiastic relation, for Caesar is a winner, Hannibal a loser; Caesar hides his delight at Pompey's death, Hannibal his disappointment in the face of defeat. The first tercet of the sestet generalizes the principle of simulazione and the second tercet specifies it of the speaker, whose singing and laughing ("rido o canto") conceal the anguished tears ("angoscioso pianto") he weeps because of his hopeless love for Laura. The almost riddling syntax of lines 9-13, which Wyatt emphasizes in his translation by reversing the order of the terms, itself exemplifies an ambiguous language of dissimulation (Ferry 102103, 107).

Tottel's rubric for Wyatt's translation of $R v f 102$, "Of others fained sorrow, and the lovers fained mirth" (Tottel, no. 50) reads Petrarch rather than Wyatt, for Wyatt's poem neither requires nor excludes an erotic context. However, in bringing together humanist learning 
(Petrarch relies on Lucan's unflattering portrayal of Caesar in the De bello civili) with the compressed elaboration of a sonnet to graph the sharp differentiation of the speaker from external circumstances, Wyatt's version of Petrarch's poem can stand at the center of his concerns as a poet, lover, and ambassador inured to the necessity of feigning in the languages of love and diplomacy. ${ }^{12}$ As Greenblatt observes (144-45), the "doubleness" of translation, which strives for equivalent terms in two languages, is homologous with the negotiation typical of diplomacy and a reflection upon the inevitable distortions of the truth and of the self-consequent on practicing it.

With the exception of the couplet, where Wyatt's formal principles dictated divergence from Petrarch, Wyatt maintains Petrarch's rhyme scheme. In the first quatrain, his rhymes Egypt and writt calque those of Petrarch (Egitto, scritto). One departure takes its cue from Velutello's gloss of "or chiara or bruna" as "hor allegra ora mesta" rendered by Wyatt as "now sad, now merry" (M\&T 264, Thomson 191-200). In the couplet, Wyatt uses assonance to capture, with the otherwise redundant "any time, or season" ("alcuna volta" in Petrarch) the unusual internal rhyme on - una in lines 12-13 of Petrarch's sonnet:

Però, s' alcuna volta io rido o canto, Whereby, if I laught, any time, or season facciol, perch' i' non ò se non quest' una It is for bicause I have nother way via da celare il mio angoscioso pianto. to cloke my care but vnder spoort and play.

Wyatt's poem concludes with pretended jollity rather than Petrarch's inner torment, sealing the poem with the necessity of dissimulation. But the most striking moment of Wyatt's version, combining fidelity to the source with poetic innovation, is the account of Hannibal's intense disappointment, which renders Petrarch's "rise fra gente lagrimosa et mesta / per isfogare il suo acerbo dispitto" (lines 7-8) as "Laught to his folke whome sorrowe did torment, / His cruel dispite for to disgorge and qwit." Included in Egerton in a version almost certainly revised for that manuscript by Wyatt (M\&T xxiii), the rare and forceful disgorge ${ }^{13}$ nearly a homophone for isfogare, seems emblematic of a courtier's revulsion before the double-dealing of court politics. It is thus suggestive that Wyatt's line translates what is close to being the stated motive of Petrarch's poetry, manifest in $R v f 293.10$, "pur di sfogare il doloroso core" but announced much earlier in the collection, as we saw, with $R v f$ 23.4, "perché cantando il duol si disacerba." ${ }^{14}$ Just as the first poem in Egerton takes up the topic of the injustice of love, which transfixes the speaker but leaves the lady untouchedan imbalance Petrarch first records in $R v f 2.13-14$-the first sonnet in Wyatt's manuscript nods to a fundamental impulse driving Petrarch's poetic collection.

The paradigmatic status of Wyatt's first proper sonnet in the Egerton manuscript may also help to explain the placement of a poem found near the end of the shorter poems (M\&T no. 81). Wyatt's strambotto, whose two first lines ("Off Cartage he that worthy warrier / Could overcome, but cowld not use his chance") imitate the first two lines of Petrarch's Rvf 103 ("Vinse Hanibàl, e non seppe usar poi / ben la vittoriosa sua ventura") adopts the same deductive logic of the contiguous Rvf 102.9 ("Et così aven..." vs. "And I like wise... ") to portray the tension between Wyatt's official diplomatic duties at the Spanish imperial court 
in 1537-which required simulazione -and a new love interest left behind in England, a tension made explicit in language that at once conflates and contrasts the uncertainties of political fortune with those of the heart's desire (Foley 52-53):

So hangith in balance

Off warr, my pees, reward of all my payne;

At Mountzon thus I restles rest in Spayne. (M\&T 81.6-8)

As we will see below, the "restless rest" of the last line is one of Wyatt's signatures, which Surrey would seize on in glorifying his predecessor. Although the Egerton manuscript is a far cry from being Wyatt's Canzoniere, the high finish of the poems transcribed by the amanuensis (continuously to poem 89 in M\&T) suggests that at some point in its existence Wyatt intended it as "an album of fair copies ready for final correction and polishing" (Harrier 3). Whether the poems are ordered by any principle other than sheer chronology appears unlikely (Daalder), but an internal patterning among the poems might nevertheless be discernible. One example might be how the strambotto (M\&T no. 81), with its use of a historical exemplum to model the speaker's erotic circumstances, answers the poem regarding Caesar and Hannibal (M\&T no. 3), itself based on the same juxtaposition, but in which the speaker's erotic preoccupation remains obscured, possibly because the earlier love-sonnets in the collection concerned Wyatt's risky relations with Anne Boleyn (Greenblatt 145-50; Foley 99-101; Walker 110-111, 286-92). From this perspective, the announcement of dissimulation in poem no. 3 is thematic for the collection.

An equally intense existential situation gives rise to Wyatt's sonnet "The piller pearisht is whearto I Lent," not in the Egerton manuscript, but in large part a translation of Petrarch (M\&T no. 236; Thomson 188-89). The poem signals the low point of the poet's circumstances after his patron and friend Thomas Cromwell was executed in 1543. The poem again illustrates the entangled relation of erotic and political contexts in Wyatt's verse, since he adapts $R v f 269$, "Rotta è l'alta colonna e'l verde lauro," the lament for the deaths of both Laura and Cardinal Giovanni Colonna, Petrarch's friend and patron, but leaves out references to the lady and the laurel as irrelevant to the shock of Cromwell's removal. In the $R v f$ poem 269 is one of the first poems to register Laura's death (first mentioned in poem 267) and forms part of a suite of mourning poems including $R v f 268$ and 270 (Martinez 10-23). As readers have observed, Wyatt thus marks a personal catastrophe with a poem from that part of Petrarch's collection that demarcated what Renaissance editors identified as the parts in vita and in morte of $R v f$ (Walker 279-82). Wyatt's first quatrain follows Petrarch's text closely, but the second departs from it; the third quatrain is a recognizable adaption of Petrarch's first tercet, while the last three lines are completely unrelated-as if Wyatt wished to reflect in formal terms the omission of half of Petrarch's explicit content. Wyatt also insists on an extreme display of sorrow, so that lines 10-12 dissolve into verbal redundancy:

What can I more but have a woful hart,

My penne in playnt, my voice in wofull crye,

My mynde in woe, my body full of smart? 
The lines deploy Wyatt's plain, monosyllabic native style, his "gauge of integrity" (Greene, Light 256), but upon inspection the verses prove surprisingly Petrarchan in inspiration. Their stimulus arrives not, however, from $R v f 269$ (Petrarch's line 11 mentions only "humidi... occhi" and "viso chino") but from the contiguous $R v f 268$. Cued perhaps by "Questa è del viver mio l'una colonna” (268.48), which attributes to Laura the column reserved for Colonna in sonnet 269-that is, performs a shift of reference that Wyatt's poem precisely reverses-Wyatt draws for his lines 11-12 on $R v f$ 268.9-10 ("ogni mia gioia / per lo suo dipartire in pianto è volta”), which resonates in turn with Wyatt's lines 5-6: “... for happe away hath rent / of all my joye, the verye bark and rynde," while 268.33 ("e questo solo anchor qui mi mantene...") is far closer to Wyatt's line 2 ("the strongest stay of myne unquyet mynde") than Petrarch's Rvf 269.2, where tree and pillar cast protective shadows rather than acting as supports. Most surprising, Wyatt's despairing final couplet, "and I myself, my self always to hate / Til dreadfull death do ease my doleful state," with its archaizing, alliterative pattern, is clearly an intensification of $R v f$ 268.29-30: "Ma io, lasso, che senza / lei né vita mortal né me stesso amo." Despite its absence from Egerton, this sonnet also seems to find a consoling and specific answer in the final section of short lyrics in that manuscript, where Wyatt in a more positive key affirms in the sonnet "If waker care" (M\&T no. 97) his love for Elizabeth Darrell using a similarly plain style ("She hath in hand my witt, my will, and all"). The sonnet adopts for the four occurrences of the B rhyme in the quatrains ("playne," etc.) the same rhyme as the couplet in "Off Carthage he" discussed above ("payne, Spayne"), and an assonant final couplet ("staye, daye"). If Petrarch closes his collection with a turn to the Virgin, Wyatt winds up the portion of Egerton dedicated to shorter poems addressing a new lady love (Braden, "Wyatt" 251-52).

The name of Henry Howard commands the title page of Richard Tottel's Songes and Sonettes written by the right honorable Lorde Henry Haward late Earle of Surrey, and other published in 1557. Himself a descendant of Edward I and III, Surrey's notoriety as a martyred aristocratic antagonist of Henry VIII lent panache to the collection, published while the Catholic Mary Tudor was still on the throne (Marquis, "Politics"; Sessions 27377). In Tottel's volume, Surrey's glamour, and his first place in the order of texts, in part obscures the elder Wyatt, a prudent gesture as Thomas Wyatt the younger had recently been beheaded as a rebel. But Surrey's conception of his task as a poet is in fact heavily dependent on the literary model suggested by Wyatt's imitations of Petrarch. Jonathan Crewe is right to see in Surrey's treatment of Wyatt virtually an attempt to transform himself into the elder poet (75-76). Thus Surrey lamented Wyatt's death in two sonnets (Howard nos. 29, 30) and in an elegy in heroic quatrains published anonymously in 1542 (Zitner; Sessions 240-59; Walker 377-413). Another sonnet (Howard no. 31, "The Great Macedon") was inserted in the Egerton manuscript to introduce Wyatt's terza rima versions of the Penitential Psalms (M\&T 98). Wyatt's imitation of Petrarch, "Caesar, when that the traytour of Egypt" (M\&T no. 3) is echoed in one of the Wyatt epitaphs (Howard no. 29), and Wyatt's 'The piller pearisht," also imitated from Petrarch, furnished the impresa of the broken column for the anonymous Arundel castle painting of Surrey surrounded by Howard emblems, made in 1543, an image closely related to the Howard heraldic claims Surrey's 
enemies exploited to have him condemned to death (Sessions 333-420, esp. 348-49, 369-72, 391-99). Surrey was moreover probably responsible-a bold gesture of condescension for an aristocrat-for the publication of John Leland's Latin panegyric Naeniae to Wyatt, where Wyatt is represented as the founder, along with Chaucer, of a national literature in emulation of the classics and the Tuscan poets (Foley 30-31, Sessions 250-51). These formulations led directly to the positive estimates of Surrey and Wyatt in Puttenham's Arte of English Poesy in 1589, and of Surrey in Sidney's Defence of Poesie in 1595, years when Shakespeare is consolidating his career.

Surrey's epigrammatic style, though markedly different from Wyatt's pithiness, consciously imitated that of the elder poet (Heale 104) and reiterated some of Wyatt's characteristic verbal formulae, e.g. his characterization of court life as "the slipper wheele / of hye astate" (Tottel no. 128.1-2; Howard no. 13.49: "that slipper state I know"). The title of Wyatt's Quyet of Mynde, a translation from Plutarch for Queen Catherine of Aragon (Walker 284-85), recurs as a formula in Surrey (Howard no. 23.32, "my restless mind"; no. 24.34, "my unquyet mynd"), in part because it recalls the sorrows of Vergil's Dido, of which more below. ${ }^{15}$ Such infusions of Wyatt's vivid phrases in Surrey's poems are consistent with the fact, as readers have noted, that several of Surrey's most effective poems are epitaphs: for Wyatt, for Surrey's beloved squire John Clare, and in a sense proleptically for himself (Howard no. 26, no. 38). For Surrey, the language of epitaphs is continuous with his affirmation of noble literary traditions; he thus adapts, for Wyatt's elegy ("the earth his bones, the heavens possesse his gost," Howard no. 28.38) and for Clare's ("Norfolk sprang thee, Lambeth holds thee dead," Howard 35.1), Donatus's famous epitaph for Vergil: “Mantua me genuit, Calabri rapuere; tenet nunc Parthenope.” 16

Wyatt and Surrey both translate $R v f 140$, "Amor, che nel penser mio vive e regna," the only instance of such duplication (M\&T no. 4; Howard no. 4; Thomson 169-79). With its presentation of Love in feudal and chivalric terms the poem had an obvious appeal to the two Tudor poets, who inhabited, each at his different rank, a refeudalized absolute monarchy, and it follows that for each poet matters of loyalty and lordship guide their adaptations of Petrarch's sonnet. Given that in Wyatt's version "love" is neither the first word nor immediately personified, the figure of Love is demoted both in rhetoric and in rank. Nor does Wyatt, as Surrey does, have love "raine and live," but only "harbar" in his thought and "take up residence" in the speaker's heart. Wyatt's love thus appears delegitimated, a challenger with "bolde pretence" to the lady's regime of self-repression (M\&T no. 4.7: “... rayned by reason, shame and reverence”). Indeed, Wyatt's only instance of rayned alters its meaning by describing the restraints ("reins") emanating from the lady, which in effect displace love's power to reign and rule. Defeated by the lady's disapproval, love's manifestation in the speaker flees to "the heart's forest," an expression, not found in Petrarch, that makes of love's latency a form of lurking in the wild, as if love were living in banishment as a brigand. Wyatt's final line, closely translating Petrarch's statement of the ethical dilemma of divided loyalties, "but in the field with him to lyve and dye," again evokes a real, possibly remembered space of shared military adversity (Petrarch gives only "star seco"). The poem ends less a love sonnet than a celebration of brothers-in-arms, 
lending an air of outlaw activity to Wyatt's erotic adventures (Greene, Light 252-53, Ferry 114-16, Heale 96-97, Foley 95).

Surrey's version continues Wyatt's trend toward more concrete and experientially vivid feudal contexts: Petrarch's Love armato is expanded to "clad in the armes wherein with me he fought." ${ }^{17}$ But the conclusion of Surrey's version modifies his models dramatically (lines 12-14):

Che poss'io far, temendo il mio signore, For my lordes gylt thus fawtless byde I payne:

Se non star seco infin a l'ora extrema?

Yet from my lorde shall not my foote remove.

Ché bel fin fa chi ben amando more.

Sweet is the death that taketh end by love.

Casting the scene as a suicidal last stand with a heart entirely pure is unalloyed Howard mythmaking, a heroic and romanticized gesture authorized, beyond Petrarch or Wyatt, with a subtext from Vergil's Aeneid. Line 13 reflects Aeneas's promise to stay by his father Anchises during the sack of Troy, "mene efferre pedem, genitor, te posse relicto / sperasti ...?” (Aeneid II.657-58; see Howard 105), which Surrey in his translation of the Aeneid renders as: "Father, thoughtst thow that I may ones remove ... a foote, and leave thee here behinde?" (Howard no. 41.864-66). ${ }^{18}$ Indeed the preceding lines of Aeneas's account, as Englished by Surrey, are a precise gloss on Surrey's deepest motives: "Driven I was to harness then againe, miserably my death for to desire. For what advise or other hope was left?" (Howard no. 41.862-64). The idea of dying nobly for a lost cause resonated all too strongly with the aristocratic pretensions and cultural politics of the Howards, attitudes increasingly risky in the final years of Henry's tyranny.

Much of Surrey's poetic program and aristocratic politics are thus implicit in line 13, “fawltless byde I payne," a phrase nonexistent in Petrarch's text. Surrey's rhyme scheme is, anomalously for most sonnets, ABAB, CDCD, ECEC, FF, with "payne" concluding the C rhymes that begin in the second quatrain. But the progress of the $\mathrm{C}$ rhyme into the sestet, though a fault in Italian sonnet aesthetics, is part of Surrey's point. By insisting on the importance of the -ayne rhyme, Surrey puts into high relief the distinctive "raine" in the first line and also links his sonnet metrically with his two elegiac sonnets for Wyatt, which also bring a rhyme from the first two quatrains into the third. ${ }^{19}$ Through a similar pattern of rhymes and other verbal echoes, further links to Wyatt's work and biography emerge in a sonnet of Surrey's with no known model, Petrarchan or other, "The fansy which that I have served long” (Howard no. 10). ${ }^{20}$ Surrey's final couplet, "Where I am now, as restlesse to remayne, / Against my will, full pleased with my payn”-another carefully crafted doublebind-echoes the first line of Surrey's own epicedium for Wyatt in heroic quatrains, "Here rests Wyatt, who could never rest" and alludes to the conclusion of Wyatt's strambotto on his forced residence during his Spanish embassy, "At Mountzon thus I restles rest in Spayne," a situation existentially replayed by Surrey's own encampment "amiddes the hylles in base Bullayn" (no. 10.12). The reiterated "restless rest" has special resonance as an 
epigram for Wyatt's characteristically conflicted energy, indeed constitutes a behavioral impresa transferred into the language of Surrey's epicedium for Wyatt from the epitaph of the celebrated Italian general Gian Giacomo Trivulzio, the victor of Agnadello and Marignano, who died in 1518: "Hic mortuus requiescit semel / qui vivus requievit nunquam"(Hudson 543).

Both the Virgilian intertexts deposited in the Petrarchan adaptations and the insistent associations with Wyatt are aspects of Surrey's strategy of self-authorization, by which, as many readers have suggested, Surrey fashioned what for eighteenth-century readers was the first flowering of a native English classicism (Howard xi), while for William Sessions (24059) Surrey's program aimed at nothing less than the renovatio of English poetry and English nobility. The strategy permeates Surrey's entire oeuvre and is the chief vector of his Petrarchan adaptations, for Surrey does not attempt close translations like those of Wyatt. Instead, in the case of two sonnets springing from Petrarchan originals, "The soote season" (cf. $R v f 310$, "Zefiro torna") and "Alas, so all thinges" (cf. Rvf 164, "Hor che' l ciel"), he articulates his poems around the same Virgilian locus classicus that organizes Petrarch's two sonnets: Dido's nocturnal anguish contrasted to the peaceful repose of nature (Aen. IV.522-32). ${ }^{21}$ Thus Surrey transfuses into his own poetry not only Aeneas's heroic bravado, as in "Love that doth rayne," but Petrarch's recurrent staging of Dido's passion, which serves as an expression of Surrey's vulnerability and of that "unquyet mynde" (as we saw, a formula also imparted by Wyatt).

Surrey's Petrarchan, but also Vergilian, Dantean, and Chaucerian tradition-nor can Wyatt be absent-is summarized in the first poem anthologized in Tottel, a capitolo in terza rima that functions as a posthumous manifesto of Surrey's planned renovatio. Though the poem proclaims an overt purpose of erotic persuasion (lines 50-51, "oneless this carefull song / Prynt in your hert some percell of my will") it is more the proclamation of a poetic and cultural program. That Surrey's "percell of my will" is echoed in Tottel's preface to the reader ("that to have wel written in verse, yea and in small parcelles, deserveth great praise") brands the poem as the prime example of how English poets can match the "works of divers Latines, Italians, and other" (Tottel 1). This attempt at the edification of a literary tradition through the emulation of Latins and Italians is visible in the translation of Petrarchan passages where Virgil is also implicit, and in Surrey's wielding of the terza rima, a gesture that does homage to Wyatt, who first uses the form in English in his satirical epistles and penitential psalms, as well as to Petrarch's Trionfi, a portion of which Surrey translates in his "Such waiward wayes has love" (Howard no. 13, see 113-14)—and ultimately to Dante.

"The sonne hath twyse brought forthe the tender grene" is a catalogue of the speakerlover's disquiet and alienation, a melancholy brought on by repression ("so doth each place my comfort cleane refuse”; see Sessions 185-87). After a Chaucerian opening imitated from Troilus commenting on the approaching winter (V.8-11), the poem runs through a series of Petrarchan borrowings: line 18, "at hand to melt, farr off in flame to bourne" originates in Petrarch's "s'arder da lunghe et agghiacciar da presso" ( $R v f 224.12$, a poem translated by 
Wyatt); lines 21-29 follow the opening of Petrarch's first sestina, $R v f 22.1-6$, a borrowing that modulates seamlessly into Surrey's

And me withdrawe from everie haunted place,

Lest in my chere my chaunce should pere to playne;

And with my mynd I measure paas by paas

To seke that place where I myself hadd lost... (Howard no. 11. 32-35)

These lines render the first quatrain of "Solo e pensoso i più deserti campi / vo mesurando a passi tardi e lenti"-the only known translation into English of these lines until the eighteenth century-and, from $R v f$ 175.1-2, "Il tempo e'l loco / ov' i' perdei me stesso." Lines 40-43 develop the ship allegory ("My sayles do fall...") familiar from Chaucer's and Wyatt's versions of $R v f$ 189. Finally, lines 47-49 derive from $R v f 209.9-11$ :

e, qual cervo ferito di saetta

ch'el ferro avvelenato dentr'al fianco

fugge, e più duolsi quanto più s'affretta
And yf I flye, I carrey with me still

the venymed shaft which doth his force restore

by hast of flight...

But Surrey is also mindful of Aeneid 4.69-73, which describes Dido afflicted by love as a wounded deer ("Qualis coniecta cerva sagitta...”), thus returning to the topic of Dido's nocturnal anxiety, already touched on in the borrowing from the sestina (line 24, "save I, alas, against all others use") that renders Petrarch's adversative conjunction "Et io..." ( $R v f$ 22.6), which echoes in turn Vergil's “At regina...” from Aeneid 4.1 and 4.529.

A half dozen Petrarchan borrowings in a poem of 55 lines constitutes a tour de force of quasi-centonic poetry, but from the point of view of Surrey's politics, the poem exhibits more than poetic colors: the reference to long-hidden unhealed wounds (lines 5-6, "Sins I have hidd under my brest the harme / that never shall recover helthfulness") is a formula in Surrey's poetry for his long-simmering aristocratic resentment under the Tudor yoke. Sessions suggests that for Surrey Dido's wound represents "the vulnerability of all human nature" (284-86) and thus it is no accident that Surrey paraphrases, near the beginning of his capitolo, Virgil, Aen. 4.67 ("tacitum vivit sub pectore volnus"). ${ }^{22}$ The fixation on the wound also comes explicitly through Wyatt. Surrey concludes a strambotto with "But Wiat said true, the skarre doth aye endure," (Howard no. 34) echoing, from Wyatt's double sonnet preserved in Tottel (which is significantly given the profoundly Petrarchan heading "The lover describeth his restlesse state") ${ }^{23}$ Wyatt's statement on the ineradicable scars of love: "From whence no toole away the skar can race" (Tottel no. 105.14; see also M\&T no. 101.910). ${ }^{24}$ The association of the wound, the stricken deer, and the vulnerability of even a royal self would return at the end of the century to inform Hamlet's satisfied observation of Claudius's conscience stung by the players' performance of "The Murder of Gonzago": "Why, let the stricken deer go weep..." (Hamlet, III.ii.206).

\section{Shakespeare's Petrarch berhymed}

If Tottel's anthology institutes a Petrarchizing program, it also concludes an epoch: George Watson (1-3) has commented that after Tottel Petrarch is rarely the object of direct 
translation among English sonneteers, possibly for reasons of religion and ideology, since Petrarch was a Papist, but also possibly because translating Petrarch is so difficult. In any case, after Surrey's establishment of the English sonnet including up to seven rhymes, there was no going back to the Petrarchan sonnet in four or five rhymes that Wyatt strove to master. Despite this shift in his reception, Petrarch's reputation remained intact, even though the primary reason for invoking him is in order to rival or outdo him, or, as in Sidney's case, in order to accuse rivals of borrowing from him too liberally (Astrophel no. 15.7-8).

The idea of rivaling and besting Petrarch did not escape Shakespeare's ambition. Tottel's Songs and Sonettes is mentioned in the first scene of Merry Wives, and one of its songs (no. 182) is paraphrased in Hamlet's gravedigger scene (V.i.55-62), suggesting Shakespeare's ownership of a book that had been reprinted eleven times from 1557 to 1593 and that included some thirty Englished lyrics by Petrarch. Judging from Shakespeare's celebrated parody of fulsome Petrarchan comparisons in one of his own sonnets, "My Mistres eyes are nothing like the Sunne" (no. 130), it has been convincingly argued that Shakespeare knew the seventh poem in Thomas Watson's collection Hekatompathia (1582). Significantly, the poem is placed amid a series of poems (nos. 5-8) that either translate or refer to Petrarch (Pearlman; Mortimer 20, 63).

Most readers agree that Shakespeare's sonnets as published in 1609 betray scant employment of Petrarch, ${ }^{25}$ although lines 11-12 of Sonnet 130 itself, "I graunt I neuer saw a goddesse goe; / My Mistres when shee walkes treads on the ground," have been perceived as targeting Petrarch's praise of Laura's walk beginning the sestet of $R v f 90$ ("Non era l'andar suo cosa mortale / ma d'angelica forma...”). If Shakespeare did indeed fix on $R v f 90$ as symptomatic of Petrarchan hyperbole, he showed a shrewd selectivity. It may be that the negations that articulate Shakespeare's sonnet (line 6, "But no such Roses see I in her cheekes”) derive from Petrarch's strong negation, though with contrary intention, beginning his sestet-the very lines Shakespeare imitates. In other words, Petrarch is challenged on his own ground. But if Shakespeare refuses to call his own mistress's eyes solar, he does permit his character Romeo to address Juliet more than once as a sun ("it is the East, and Juliet is the sun”) a comparison plausibly authorized by Petrarch's praise of Laura in these terms (Rvf90.12-13: “... un vivo sole / fu quel ch' i ' vidi.”). ${ }^{26}$

Romeo and Juliet is indeed more promising as a site of Shakespeare's confrontation with Petrarch and Petrarchism. The date of 1594 or 1595 for composition of the play would justify viewing the prominence of sonnet form and sonnet topics in the text as, in part, Shakespeare's response to the barrage of English sonnet sequences published between 1591 and 1594. In a larger sense it is part of the continuous exploitation of the sonnet that goes back to the many editions of Tottel, the collections of Thomas Watson $(1576,1582)$, and the enhancement of Petrarch's status by his treatment as a past master in such works as Leland's eulogy for Wyatt (1542), Puttenham and Sidney (Parker 1939, Harris, Pearlman). The better sonnetteers of 1591-94 allude to Petrarch, typically but once (e.g. Sidney, Astrophel no. 15; Daniel, Delia no. 35; Drayton, Ideas Mirrour, dedication). Thus it is striking that the only mention of an Italian poet in Shakespeare's entire corpus is Mercutio's of Petrarch, a 
mention all the more significant, as Peter Holland notes in his introduction, considering the importance given to proper names in the play (Shakespeare, Romeo and Juliet xxxvi):

Without his roe, like a dried herring. O flesh, flesh, how art thou fishified! Now he is for the numbers that Petrarch flowed in. Laura, to his lady, was a kitchen wench (marry, she had a better love to berhyme her..."), Dido a dowdy, Cleopatra a gypsy, Helen and Hero hildings and harlots, Thisbe a grey eye or so...

(Rom. II.iv. 37-43)

The single mention of Petrarch may reflect that in Shakespeare's most immediate source for his script, Broke's versified Romeus and Juliet (published by Tottel in 1562), it is another Tuscan author, Boccaccio, who is cited as fitter than Broke himself to tell the tale. ${ }^{27}$ As in Tottel's two poems that name Petrarch (nos. 188-89), Mercutio sets up Petrarch as the expert sonneteer and Romeo as his inadequate challenger. ${ }^{28}$ The comparison implies that Romeo, unmanned by love, is like the chaste Petrarch who "flows in numbers" to "berhyme" his lady. Both lady and lover are part of the competition, since the business of praising Laura is one of coining comparisons (to Dido, Helen, Hero, Thisbe) to their detriment (they are mere “kitchen wenches”). Mercutio’s mocking mention of Petrarchan verse is a kind of fulcrum in the play for Shakespeare's engagement with Petrarch's text and example, and the insistence on the question of rival poets and rival ladies tips us off that the play itself is Shakespeare's bid to outdo Petrarch within the arena of the sonnet and its poetics.

As many readers have observed, the formal principle of the sonnet itself, in the form that Surrey bequeathed to the Elizabethans, has a prominent role in the play. Complete sonnets appear both as the prologue to the play and, in the second Quarto, at the beginning of Act II. ${ }^{29}$ Some who write on this subject claim that after Act II Shakespeare loses interest in the sonnet as a formal principle, or abandons it as Verona descends into violence, as if the sonnet represented civic harmony: both ideas result from a limited view of what sonnet form could mean in Shakespeare's time. Not only could "sonnet” refer to any short poem (as in the title to Tottel's collection), but typographical convention often isolated the sestet of sonnets from the octave, as occurs in Sidney's Arcadia (1590 and 1593), Thomas Lodge's Rosalynd (1593) and Drayton's Ideas Mirrour (Harris 467). More radically, Watson's translations of Petrarchan sonnets expanded the form from quatorzains to three sestets (quatrains rhyming $\mathrm{ABAB}$ and an added couplet). What this means for Shakespeare is that the final six lines of Romeo and Juliet, a quatrain and a couplet, functions as a sonnetfragment, or as a strambotto (the form cultivated by Wyatt and Surrey), concluding the work in the same way the sonnet-prologue begins it. In this light, a number of other passages are recognizable as sestets, or strambotti, including speeches by Benvolio (I.ii.45-50), Romeo (I.ii.90-95), and Paris, this last late in the play (V.3.12-17) (Shakespeare Rom. xxxiv-v). Thus in no sense does Shakespeare forget about sonnet form after Act II, and the persistence of sonnet form is one of the ways in which, as Anne Slater as argued (132-36), a myriad of elements in the play realize the poetics of the sonnet, including its rhetoric, figurative language (e.g. oxymoron), and its implicit narratives. 
The chief example of how Shakespeare adapts the sonnet to the requirements of a play is of course the meeting of Romeo and Juliet (I.v.94-111), where Shakespeare gives the first quatrain to Romeo, the second to Juliet, and shares the lines of the third quatrain between them (one to Juliet, three to Romeo); the witty final couplet is then divided between the two:

[Juliet]: "Saints do not move, though grant for prayers' sake."

[Romeo]: “Then move not while my prayers' effect I take.” (I.v.106-07)

As if starting another sonnet, the pair then shares a further quatrain, alternating lines, but are interrupted by the Nurse. ${ }^{30}$ In doling out the lines, Shakespeare uses the articulations of the form to suggest the coming together of the pair and the joining of their hands and lips: some modern stage directions indicate the kiss after the first line of the additional quatrain, but the kiss must occur immediately after Romeo's "I take," with the physical kiss mirroring the conclusion of the couplet, a conceit that the new quatrain continues, such that the first hemistich of its last line is divided by the second kiss ("'give me my sin again"”). "You kiss by th' book," Juliet's remark chiding Romeo's facile expertise, alerts the reader to the literary artifice of the scene, with its conceited metaphors (pilgrims, hands, lips, etc.), and Juliet's casuistical defensive reasoning ("Palm to palm is holy palmer's kiss") (Rom. xxxiv). But the sonnet transgresses the Petrarchan canons that Mercutio, in chiding Romeo in Act II.v, mistakenly applies to a Romeo no longer besotted with Rosalind. In having Romeo and Juliet touch hands and touch lips, Shakespeare flouts Petrarchan prohibitions as does Sonnet 130, where unlike the ethereal Laura, Shakespeare's love "treads on the ground." The sonnet itself is the weapon of choice in Shakespeare's duel with Petrarch, in whose songbook love never touches the pitch of the physical.

The meeting of the lovers is the most important scene in the play, since everything follows from it: everything also follows, therefore, from the kiss that the sonnet enacts. Shakespeare indicates the generative implications of the scene for the plot by placing just before the sonnet Tybalt's hostility to Romeo's attendance at the Capulet feast and his vow of revenge in terms that defy the hospitality old Capulet offers Romeo: "this intrusion shall / now seeming sweet, convert to bittrest gall" (I.v.92-3)—-terms that nevertheless remain within a sonnet idiom and which then recur in the sonnet opening Act II.i.14, "tempering extremities with extreme sweet." Just after the shared sonnet in Act I the lovers realize that their love spawns oxymora and contradiction (I.v.119-20: "Is she a Capulet? / O dear account, my life is my foe's debt”) and (I.v.139; “my only love, sprung from my only hate”), and this predicament too appears in the Act II sonnet, where the lovers must "steal love's sweet bait from fearful hooks" (line 8). Long recognized as a chief example of Petrarchan rhetoric in the play (Slater 132-33), these oxymora begin with Romeo's outburst in Act I.i.174-197. Watson is again the probable immediate source (Hekatompathia 18 and 98), but also the vector through which Romeo's account of "brawling love, O loving hate” pays homage to the "icy fire" of the same Petrarchan topos that animates Wyatt's version of $R v f$ 134 (M\&T 25: "I fynde no peace and all my warr is done") and possibly even reaches back to the last line of Chaucer's version of $R v f 132$ ("For hete of cold, for cold of hete I dye"). In Friar Laurence's metaphor of raging eros ("violent delights") Shakespeare develops an image of love as an explosive force (II.vi.9-11: "like fire and powder, / which as they kiss, 
consume"), so that the lovers' physical kiss, the verbal kiss of the couplet, and the metaphorical "kiss" of explosive, fatal eros are on a figurative continuum that realizes the compressed force of the English sonnet couplet as developed by Wyatt, Surrey, and their heirs.

Mercutio's mockery of Romeo's lovesickness offers further clues to how Shakespeare mines the cardinal difficulty of sonnet form-its rhyme scheme-for vigorous verbal effects in the play. Mercutio allows that Laura had "a better poet to berhyme her"; even before that he had conjured Romeo to "appear though in the likeness of a sigh; speak but one rhyme, and I am satisfied. Cry but 'Ay me,' pronounce but 'love' and 'dove'” (II.i.8-10), unaware that Romeo had already fulfilled this task in the previous scene (I.v.49: "so shows a snowy dove trooping with crows"). Shakespeare turns into a rich poetic resource the acoustic effects of reiterated rhymes as well as the stereotypical syllables of a lover's lament. ${ }^{32}$ Mercutio's “Ay me," emerges right on cue in Juliet's meditation overheard by Romeo below her balcony (II.ii.25: “'Ay me!” “'She speaks””), and shortly thereafter she characterizes Romeo's consent to her love-which she assumes is done lightly-with the same word (II.ii.90, "I know thou wilt say 'Ay'”). Exemplifying what we might call the insistence of the letter in the shaping of character and plot, the lovers use the punning "Ay" ( = "I") in passages rich with dramatic irony and authorial self-reflexiveness: the Nurse had prophesied Juliet's erotic predisposition as a child, in her answer of "Ay" to the Nurse's remark that she would one day fall backward (I.iii.42-50), while Romeo's first "Ay" identifies him as a reader-of amatory verse, no doubt—when asked to decode the list of guests to Capulet's ball (I.ii.61-62: “Ay, if I know the letters and the language."). ${ }^{33}$ "Ay" is thus fateful, and its fatality, in both senses of the word, is announced in Mercutio's punning use of Italian "hai" to mark a rapier's fatal thrust (II.ii.26). The gravity of the term is confirmed when Juliet fears to hear the "Ay" that will certify Romeo's death after the brawls in Verona's streets (III.ii.45-47): "say thou but 'Ay,' and that bare vowel shall poison more / than the death-darting eye of a cockatrice"; also 48: "I am not I, if there be such an 'Ay'..." In a deeper sense, Shakespeare's punning on Ay/I inherits the turn toward "the inward language" of Tudor subjectivity explored by Wyatt and Surrey (Greenblatt 155), as in lines such as "Withoute Iyen I se; and withoute tong I plain" from "I fynde no peace," an insistence on the first-person pronoun that results in part from translation, as the subject pronoun is normally suppressed in Italian. But Juliet's conclusion to the same speech also alerts us to another crucial series of rhymes in the play (III.ii.50-51): "If he be slain, say 'Aye': if not, 'No.' / Brief sounds determine of my weal or woe."

To focus on a term so natural to a tragedy as "woe" might seem pointless. But the word's onomatopoeia proclaims its poetic usefulness. It may also have carried Petrarchan associations in 1595, thanks to Sidney's dismissal of "Poor Petrarch's long-deceased woes" (Astrophil 15.7) and its prominence in the versified "passions" of Thomas Watson already identified as targets for Shakespeare's transformative wit (Hekatompathia 18, 98: Shakespeare's own sonnets 44, 90, and 127 use woe in the final couplet). Scrutiny of the play suggests a careful strategy to Shakespeare's deployment of "woe" and of thematically significant terms rhyming with it: "foe," but also, of course, the name "Romeo," used over 
thirty times in the play but rarely in rhyme. When Tybalt espies Romeo at Capulet's feast he brands him "Montague, our foe," rhyming with "that villain Romeo." Mercutio's prose chaffing of Romeo's Petrarchism, quoted above, concludes with the phrase "Thisbe, a gray eye or so" rhyming with "Signor Romeo" (II.iv.42-43). In this same speech Romeo's name is the emblem of his own sorrow, for Mercutio's claim that he lacks his "roe," his masculine sexual heft, exposes the Petrarchan melancholy embedded in the remaining Oh me of his name, a lament that also complements Juliet's “Ay me” and presages his future griefs. When Mercutio is killed, Shakespeare has his name rhyme with that of Romeo, as if as a parting verbal embrace of the two friends (III.i.143-4). Although there are further important uses of "woe," as when the newlyweds contemplate their separation (III.v.35-36: "lighter and lighter it grows / more dark and dark our woes"), Shakespeare rhymes "woe” with Romeo's name only once, and this occurs in the final couplet of the play, where, as we saw, the formal principle of the sonnet, in this case a sestet or strambotto, and a rhetorical principle, the emulative comparison identifying a superlative, reach a simultaneous consummation: "For there was never story of more woe / than this of Juliet and her Romeo." ${ }^{34}$ As we saw, the powerful closure obtained with this rhyme is prepared from the beginning of the play (its first appearance is at I.i.78-79) and it attests to Shakespeare's understanding of the challenge of the English sonnet: finding and placing the rhymes, the "berhyming" of it, in short, with a view to setting up the final couplet. The triumph of the couplet is thus also the triumph of English sonnet form and formalizes the supersession of Petrarch, just as on the level of content Shakespeare's married Romeo outperforms Petrarch's chaste lover.

Much more could be said regarding Shakespeare's exploration of Romeo as a Petrarchan persona informed by the English sonnet tradition. One of the striking continuities in Shakespeare's treatment of his male protagonist is the use of the trope of the lover as a ship in describing Romeo's destiny. First deployed as Romeo approaches the Capulet's ball (I.iv.112-113: "but he that hath the steerage of my course, / direct my sail"), it recurs as he prepares to drink poison (5.3.117-18: "Thou desperate pilot, now at once run on / The dashing rocks thy seasick weary bark”), thus framing his amatory life within the terms sketched out in Petrarch's $R v f$ 189. Shakespeare's practice was stimulated by Broke, who repeatedly applies the trope to Romeo (Broke 9, 13, 30, 51), but Shakespeare was likely not unaware that the ship-allegory of the lover ultimately derives from Petrarch, mediated by Chaucer's second canticus Troili and Wyatt's "My galy charged with forgetfulness." ${ }^{35}$ Other passages where the Rosalind-besotted Romeo behaves in extreme Petrarchan fashion, albeit mocking the mannerisms of a mutable infatuation, also reveal Shakespearean uses of topics from sonneteering tradition. Mercutio's remarks on Romeo transfixed by love's arrow and Rosalind's invulnerability to it are commonplaces (I.i. 207-15; I.iv.19-22; II.iv.13-16), but they are emblematic ones, and they link Romeo specifically to $R v f$ 2.13-14 (translated, anonymously, in Tottel, no. 227), to Troilus smitten by Criseyde in Chaucer's romance, and to Wyatt's "Behold, Love" beginning the Egerton manuscript. Montague's observation that Romeo repairs in the morning to his darkened room is in the spirit of Petrarch's sonnet on his chamber and his bed, his cameretta ( $R v f 234)$, a poem imitated by Wyatt in three stanzas of rhyme royal (Tottel, no. 67, using the same measure Chaucer used for $R v f 132$ ), and 
marked by the "unquyet mynde" formula (67.4: "quieter of mynde, mine unquiet fo"). Indeed, the whole account given by Benvolio of Romeo's solitary morning walks and concealment in the woods (I.i. 17-42), a disappearing act Romeo repeats just after Capulet's ball (II.i.30-42), is arguably an homage to Surrey's capitolo where it draws on $R v f 6$ ("Solo e pensoso") and 22 ("A qualunque animale"), passages the more conspicuous given that Surrey's capitolo holds first place in Tottel's anthology. ${ }^{36}$ In short, Shakespeare's account of Romeo as a Petrarchan lover owes a debt to Surrey's own extensive self-fashioning, ${ }^{37}$ and both acts of myth-making draw, directly and through intermediaries like Broke, on Chaucer's Troilus as the model of the noble lover undone by frustrated love and frustrated ambition. ${ }^{38}$ Viewed from this angle, Shakespeare's sonnet tragedy is a lineal descendant of Chaucer's Petrarchan translations in Troilus and Criseyde.

${ }^{1}$ See Levenson 24, also Ferry 73, citing Tottel no. 206.35-36.

${ }^{2}$ In a forthcoming study, Alison Cornish, drawing on the translation theory of Walter Benjamin, argues that Boccaccio and Petrarch, along with Dante, avoided volgarizzamento in favor of translation directed to produce a new, living work.

${ }^{3}$ Coluccio Salutati's Latin version of this hemistich ("Si fors non sit amor," drawn from an earlier version of the sonnet) appears consistent with Chaucer's (see Wilkins 169; Rossiter 119); on the poetic quaestio, see Petrarca Canz. 643; Kaylor cites Boece I, pr. 4: 201 ("And yif God ne is, whennes comen gode thynges?") as impinging on Chaucer's translation. Cf. Boccaccio, Filostrato 6.15.1-2, which conforms to the usual reading.

${ }^{4}$ Cf. Dante’s “dolce ber che non m’avria mai sazio” (Purg. 33.138).

${ }^{5}$ For Petrarch's treatment of the canzone stanza, see Durling in this volume. Rossiter (117) suggests that Chaucer might have read $R v f 189$ transcribed as two adjacent seven-line blocks, possibly suggestive of his own seven-line stanza; this is not the format used for sonnets in the Chigi ms., however. For the implications of sonnet transcription formats, see Storey in this volume.

${ }^{6}$ If in possession of a complete Petrarch, Chaucer could of course have seen Boccaccio's incipit to Filostrato V.62 as Rvf70.40.

${ }^{7}$ See Santagata's note to 105.90 (Petrarca 501) for this predicament in $R v f$ (e.g. $R v f 182.5$ )

${ }^{8}$ On the debate, see Balduino, Velli 183-99, Branca 323-25, Santagata 246-70, Petrarca Canz. 520-21; Tonelli 206-219.

${ }^{9}$ On the complex placement of these poets as subjects in Tudor society and power politics, see Greenblatt 126-39, 154-56, Ferry 107, Heale 87, and Foley 37.

${ }^{10}$ Seventy-eight poems of 280 in the second edition give "the lover" as subject of the poem's heading. See Kamholtz, Tottel xv-lxii; Marquis, and especially Marquis, "Politics," on the implications of revisions in Tottel's second 1557 edition.

${ }^{11}$ Muir and Thompson, Collected Poems of Sir Thomas Wyatt (hereafter M\&T) print the poems of the Egerton ms. in order, with some slight modifications concerning the end of the manuscript; see M\&T, xi-xii. 
${ }^{12}$ On Wyatt's poetic language as conditioned by his diplomatic skill, see Greenblatt 139-45, Heale 97, 104, Foley 22-25, Crewe 46, and Walker 335-50. It was probably during Wyatt's diplomatic missions to France in 1526 and Rome in 1527 that he encountered copies of Rvf.

${ }^{13}$ Only one attestation in OED previous to Wyatt's use: “disgorgith their veneme" (Skelton, 1529).

${ }^{14}$ Tottel's anonymous version of $R v f 23$ (no. 154) makes this line the poem's incipit, "Syth singyng gladdeth oft the harts."

${ }^{15}$ The "unquyet mind" of course also evokes Augustine's "inquietum cor noster" (Confessions I.1), a text that informs Petrarchan self-consciousness.

${ }^{16}$ On the Clare sonnet-epitaph, see Zitner; Crewe 64-65; on Surrey's Windsor poems, Sessions 108-139. For Zitner, Surrey's application of the Virgilian epitaph to Clare, never a poet, suggests the epitaph rebounds on Surrey himself (524-25).

${ }^{17}$ Ferry 114-16; see Sessions 207 on Surrey's highly successful jousts in 1540 in honor of Anne of Cleves.

${ }^{18}$ On the Aeneid translations, published by Tottel in the same year as Songes and Sonnettes see Sessions 268-77.

${ }^{19}$ See in "In the rude age" (Howard no. 30, D rhyme -ayme from the second quatrain is also in the third; E rhyme is ayle, assonant with -ayne, -ayme); "Dyvers thy death" (Howard no. 29: first quatrain B rhyme - edd, also in third quatrain; final couplet rhyme -ayle). Tottel gives as Surrey's first line "Love that liveth and reyneth in my thought" and "corrects" to Playnes and pains the second set of rhymes on -ayne in the third quatrain, obscuring the affiliation with the sonnets for Wyatt.

${ }^{20}$ Petrarchan topics are echoed, however: the first line rephrases $R v f 140$ translated by Wyatt, and lines 8-9, “...Alas, those dayes / In vayn were spent...” evoke $R v f 1.13-14$.

${ }^{21}$ The sonnets are also linked by anomalous rhyme schemes: "Soote season," three quatrains $\mathrm{ABAB}, \mathrm{CDCD}$, etc., and couplet AA; "Alas, so all thinges," three quatrains ABAB, etc., and couplet BB, suggesting that the poems are complementary by design.

${ }^{22}$ Surrey in his version of Aen. 4.83 renders the lines as "whiles in the breast the silent wound keeps life"; see Sessions 272-73.

${ }^{23}$ Tottel includes six headings that describe poems as voicing the "restless state" of the lover: nos. 1, 4, 24, 67, 104, 156.

${ }^{24}$ Wyatt versifies "Etiam sanato vulnere, cicatrix manet," attributed to Publilius Syrus and used in texts of canon law, to denote the persistence of infamy after penance and absolution. The relevance of the concept, given Wyatt's and Surrey's imprisonments, is obvious. Thanks to Justin Steinberg for bringing the legal concept to my attention.

${ }^{25}$ An echo of $R v f$ 1.9-10 ("Ma ben veggio or sì come al popol tutto / favola fui gran tempo...") has been detected in the opening of Sonnet 110 ("Alas 'tis true, I have gone here and there / and made my selfe a motley to the view”): see Rollins, cited in Braden 163.

${ }^{26}$ The sun as object of comparison is a fixture of Romeo and Juliet. see I.i.117, I.ii.94-95, II.ii.2-4, II.iii.1-6, III.ii.1-4, III.v.1-36, etc.

${ }^{27}$ Broke, p. 1, line 15: "Which Boccace scant, not my rude tongue, were able forth to tell." 
${ }^{28}$ Compare Tottel no. 188.1-3: "O Petrarke hed and prince of poets al, / Whose lively gift of flowing eloquence / Wel may we seke..."; and line 13: "But ther was never Laure more then one." But no. 189.11 in Tottel claims that Laura has been excelled; "If Lawra livde she would her cleane deface" (Heale 105). Samuel Daniel acknowledges his insufficiency as the berhymer of Delia in no. 35.3 of his 1592 collection: "though thou a Laura hast no Petrarch found."

${ }^{29}$ Broke's poem also begins with a preface consisting of a pair of sonnets and a sonnetargument (lxvii-lxix; see Harris 455-56).

${ }^{30}$ On this sonnet and sonnet poetics in Romeo and Juliet in general, see Colie 143-44, Foster 51, Laird 206-07, Levenson 23-28, Whittier 35-36, Vendler 166-68.

${ }^{31}$ For the placement of the kiss, see Franson 2-3. The kisses may echo Sidney's sonnets ending with Astrophil kissing Stella, e.g. 73,74, 79, 80, 81,84, the only "conquest" of Astrophil's courtship.

${ }^{32}$ On acoustic effects in the play, see Slater 142-44 and Patricia Parker 368. For Shakespearean autobiography in Romeo and Juliet see Brezius 23-25.

${ }^{33}$ The list has thirteen proper names; Paris makes fourteen (I.ii.22-23; but the real fourteenth is Romeo); on the number fourteen in relation to Juliet's age and association with the sonnet, see Whittier 40, and Franson 2-3, 6.

${ }^{34}$ Broke's ending does not rhyme on the name: "there is no monument more worthy of the sight / than is the tombe of Juliet and Romeus her knight"(112).

${ }^{35}$ Old Capulet's use of the ship-allegory for Juliet at III.v.130-39 ("In one little body / thou counterfeit'st a bark, a sea, a wind") is taken by Slater as an allusion to Wyatt's version of Rvf 189 (Capulet's mention of it emphasizes his age) (129). See also Laird 208.

${ }^{36}$ Thomson cites John Harington, in the preface to Orlando furioso in English Heroical Verse of 1591, describing Dante's selva oscura as "that wandring wood of which the dolefull Petrarke complaines so often in those his sweet mourning sonets..." (174).

${ }^{37}$ On Elizabethan fictions about Surrey, including Thomas Nashe's portrait of the Earl as the lover of the "Tuscan" Geraldine, see Sessions 187-92.

${ }^{38}$ Surrey imagined himself a Troilus during his happy youth at Windsor (Howard no. 27.4); the dead faithful shepherd of Howard no. 16, a projection of Surrey, is buried next to Troilus.

\section{Works Cited}

Alighieri, Dante. Commedia. Ed. Maria Rosa Chiavacci Leonardi, 3 vols. Bologna: Zanichelli, 1999-2001. Print.

Balduino, Armando. "Reminiscenze petrarchesche nel Filostrato (e sua datazione)." In Boccaccio, Petrarca e altri poeti del Trecento. Florence: Olschki, 1984. 231-47. Print.

Barkan, Leonard. The Gods Made Flesh: Metamorphosis and the Pursuit of Paganism. New Haven: Yale UP, 1986. Print. 
Boitani, Piero. Chaucer and the Italian Trecento. Cambridge: Cambridge UP, 1983. Print.

---. The Tragic and Sublime in Medieval Literature. Cambridge: Cambridge UP, 1989. 56-74. Print.

Boccaccio, Giovanni. Caccia di Diana; Filostrato. Ed. Vittore Branca. Milan: Mondadori, 1990. Print.

Braden, Gordon. "Shakespeare's Petrarchism." In Shakespeare's Sonnets: Critical Essays. Ed. James Schifter. New York and London: Garland, 1999. 163-83. Print.

---. "Wyatt and Petrarch: Italian Fashion at the Court of Henry VIII." Annali d'Italianistica 22 (2004): 237-65. Print.

Branca, Vittore. Boccaccio Medievale e nuovi studi sul Decameron. Florence: Sansoni, 1996. Print.

[Broke, Arthur] Brooke's 'Romeus and Juliet' Being the Original of Shakespeare's 'Romeo and Juliet.' Ed. J.J. Munro. London: Chatto and Windus, 1908. Print.

Bretzius, Stephen. “Joel Fineman's 'Shakespeare’s Will.”' In Shakespeare in Theory: The Postmodern Academy and the Early Modern Theater. Ed. Stephen Brezius. The University of Michigan Press, 1997. 23-37. Print.

Chaucer, Geoffrey. Canterbury Tales. The New Riverside Chaucer. Ed. Larry Benson et al. Boston: Houghton Mifflin, 1987. 23-328. Print.

---. Troilus and Criseyde. Benson, New Riverside Chaucer. 471-586.

Colie, Rosalie. Shakespeare's Living Art. Princeton: Princeton UP, 1974. Print.

Collected Poems of Sir Thomas Wyatt. Ed. Kenneth Muir and Patricia Thomson. Liverpool: Liverpool UP, 1969. Print.

Cornish, Alison. Vernacular Translation in Dante’s Italy: Illiterature Literature. Cambridge: Cambridge UP, forthcoming. Print.

Crewe, Jonathan. Trials of Authorship: Anterior Forms and Poetic Reconstruction from Wyatt to Shakespeare. Berkeley and Los Angeles: University of California Press, 1991. 36-76. Print.

Daalder, Joost. “Are Wyatt's Poems in Egerton Ms. 2711 in Chronological Order?” English Studies 69 (1988): 205-23. Print.

Daniel, Samuel. Delia. Contayning certayne Sonnets: vvith the complaint of Rosamond. London: J. C. for S. Waterson, 1592 (Facsismile edition: Scolar Press, 1969). Print.

Diani, Dominique. "Pétrarque: Canzoniere 132.” Révue des études italiennes n.s. 18 (1972): 111-65. Print.

Drayton, Michael. Ideas Mirrour, Amours in Quatorzains. London: James Roberts, 1594. Print.

Ferry, Anne. The Inward Language: Sonnets of Wyatt, Sidney, Shakespeare, Donne. Chicago: University of Chicago Press, 1983. 71-118. Print. 
Foley, Stephen. Sir Thomas Wyatt. Boston: Twayne, 1990. Print.

Foster, Leonard The Icy Fire: Five Studies in European Petrarchism. London: Cambridge Univ. Press, 1969. Print.

Franson, J. Karl. “'Too soon marr'd': Juliet's Age as Symbol in Romeo and Juliet.” Papers on Language and Literature 31 (Summer 1996): 1-14. Web. 21 Dec. 2010. <http://findarticles.com/p/articles/mi_qa3708/is_199607/ai_n8743141/>.

Greenblatt, Stephen. Renaissance Self-Fashioning. Chicago: University of Chicago Press, 1980. 115-56. Print.

Greene, Thomas. "Petrarch and the Humanist Hermeneutic." In Italian Literature: Roots and Branches. Eds. Giosuè Rimanelli and Kenneth Atchity. New Haven: Yale UP, 1976. 21024. Print.

---. The Light in Troy. Imitation and Discovery in Renaissance Poetry. New Haven: Yale UP, 1982. 242-63. Print.

Harrier, Richard. The Canon of Sir Thomas Wyatt's Poetry. Cambridge, Mass.: Harvard UP, 1975. Print.

Harris, William O. "Early Elizabethan Sonnets in Sequence.” Studies in Philology 68 (1971): 451-69. Print.

Heale, Elizabeth. Wyatt, Surrey, and Early Tudor Poetry. Chicago and London: The University of Chicago Press, 1983. 71-113. Print.

Howard, Henry. Earl of Surrey, Poems. Ed. Emrys Jones. Oxford: Oxford UP, 1964. Print.

Hudson, H.H. "Review of Tottel's Miscellany 1557-87, by H.E. Rollins.” Modern Language Notes 45 (1930), 541-43. Print.

Kamholtz, J.Z. “Thomas Wyatt's Poetry: The Politics of Love.” Criticism 20 (1978): 349-65. Print.

Kaylor, Jr., N. H., "Boethian Resonance in Chaucer's Canticus Troili.” Chaucer Review 27 (1993): 219-27. Print.

Laird, David. "The Generation of Style in Romeo and Juliet." Journal of English and Germanic Philology 63 (1964): 204-13. Print.

Levenson, Jill L. “The Definition of Love: Shakespeare's Phrasing in Romeo and Juliet." Shakespeare Studies 15 (1982): 21-36. Print.

Lodge, Thomas. Rosalynd. Euphues golden legacie. London: Thomas Orwin, 1590. Reprinted in The Complete Works of Thomas Lodge. Ed. Edmund Gosse, 4 vols. Glasgow: Hunterian Club, 1883. Vol. I, 117-18. Print.

---. Phillis Honoured with Pastorall Sonnets, Elegies and amorous delights. John Busbie, 1593. Reprinted in Elizabethan Sonnets. Vol. II. Ed. Sidney Lee. Westminster: Archibald Constable, 1904. Print. 
Marquis, Paul A. "Recent Studies in Richard Tottel's Songes and Sonnettes." English Literary Renaissance 28 (1998): 299-313. Print.

---. "Politics and Print: The Curious Revisions to Tottel's Songes and Sonettes." Studies in Philology 97 (2000): 145-64. Print.

McLaughlin, Martin. Literary Imitation in the Italian Renaissance. Oxford: Oxford UP 1995. 22-48. Print.

Martinez, Ronald L. "Mourning Laura in the Canzoniere: Lessons from Lamentations." Modern Language Notes 118 (2003): 1-45. Print.

Mason, H.A. Humanism and Poetry in the Early Tudor Period. London: Routledge \& Kegan Paul, 1959. Print.

Mortimer, Anthony, ed. Petrarch's Canzoniere in the English Renaissance.. Amsterdam and New York: Rodopi, 2005. Print.

Natali, Giulia. “A Lyrical Version: Boccaccio’s Filostrato.” In The European Tragedy of Troilus., Ed. Piero Boitani. Oxford: Clarendon Press, 1989. 49-74. Print.

Parker, Patricia. "Shakespeare’s Sound Government: Sound Defects, Polyglot Sounds, and Sounding Out.” Oral Tradition 24 (2009): 359-72. Print.

Parker, W.R. “The Sonnets in Tottel’s Miscellany.” PMLA 54 (1939): 669-77. Print.

Pearlman, E.H. "Watson's Hekatompathia in the Sonnets and Romeo and Juliet." English Studies 74 (1993): 343-51. Print.

Petrarca, Francesco. Canzoniere. Ed. Marco Santagata. Milan: Mondadori, 1996. Print.

---. Le Familiari [Familiarum rerum libri XXIV]. Ed. Vittorio Rossi, 4 vols. (Vol. 4 ed. Umberto Bosco). Florence: Sansoni, 1933-1942. Print.

---. Petrarch's Lyric Poems: The Rime sparse and Other Lyrics. Ed. and trans. Robert M. Durling. Cambridge, MA: Harvard UP, 1976. Print.

Picone, Michelangelo. "Il sonetto CLXXXIX.” Lectura petrarce 9 (1989): 151-77. Print.

Pigman III, G. W. "Versions of Imitation in the Renaissance." Renaissance Quarterly 33 (1980): 1-32. Print.

Puttenham, George. The Arte of English Poesy. Ed. Frank Whigham and Wayne Rebhorn. Ithaca: Cornell University Press, 2007. Print.

Powell, Jason. “Thomas Wyatt's Poetry in Embassy: Egerton 2711 and the Production of Literary Manuscripts Abroad." The Huntington Library Quarterly 67 (2004): 261-82. Print.

Rossiter, William T. Chaucer and Petrarch. Cambridge: D.S. Brewer, 2010. Print.

Santagata, Marco. Per moderne carte: la biblioteca volgare di Petrarca. Bologna: Mulino, 1990. 246-70. Print. 
Sessions, W.A. Henry Howard, the Poet Earl of Surrey. A Life. Oxford: Oxford UP, 2003. Print.

Shakespeare, William. Romeo and Juliet. Ed. Peter Holland. New York: Penguin, 2000. Print.

---. Shakespeare's Sonnets, A Facsimile of the Chalmers-Bridgewater Copy (Aspley Imprint) of the 1609 Quarto, in the Huntington Library. Converted into Digital Format by R.G. Siemens. Calgary, AB: U of Alberta, 1998. Web. 21 Dec. 2010. <http://extra.shu.ac.uk/emls/Sonnets/Sonnets.html>.

---. The most excellent and lamentable tragedie of Romeo and Iuliet. London: Thomas Creede, 1599. Internet Shakespeare Editions. Victoria, BC: University of Victoria, 18 Dec. 2009. Web. $\quad 21 \quad$ Dec. 2010. <http://internetshakespeare.uvic.ca/Library/facsimile/bookplay/BL Q2 Rom/Rom/>.

Sidney, Sir Philip. Astrophel and Stella, prepared from Alexander B. Grosart's The Complete Poems of Sir Philip Sidney [1877] by Risa S. Bear at the University of Oregon. Eugene: University of Oregon, 1995. Web. 21 Dec. 2010. < http://www.luminarium.org/renascence-editions/stella.html>.

---. The Defence of Poesie, 1595. Menston: Scolar Press, 1968. Print.

Slater, Anne P. "Petrarchanism Come True in Romeo and Juliet." In Images of Shakespeare, Proceedings of the Third Congress of the International Shakespeare Association, 1986. Ed. Werner Habicht, D.J. Palmer and Roger Pringle. Cranbury, NJ: Associated University Presses, 1988. 129-50. Print.

Smith, Hallett. “The Art of Sir Thomas Wyatt.” Huntington Library Quarterly 9 (1946): 32355. Print.

Stillinger, Tom. The Song of Troilus: Lyric Authority in the Medieval Book. Philadelphia, Pa.: University of Pennsylvania Press, 1992. Print.

Thomson, Patricia Sir Thomas Wyatt and his Background. London: Routledge \& Kegan Paul, 1969. 149-208. Print.

Tonelli, Natascia. "Petrarca ( $R v f$ 2-3), Boccaccio e l'innamoramento nel tempio.” Studi sul Boccaccio 28 (2000): 198-219. Print.

Tottel, Richard. Richard Tottel's Songes and Sonettes, The Elizabethan Version. Ed. Paul A. Marquis. Tempe, Arizona: Renaissance English Text Society and Medieval and Renaissance Text Society, 2007. Print.

Tromly, Frederic B. "Surrey's Fidelity to Wyatt in 'Wyatt Resteth Here." Studies in Philology 77 (1980): 376-87. Print.

Velli, Giuseppe. "La poesia volgare di Boccaccio e i 'rerum vulgarium fragmenta' : primi appunti.” Giornale storico di letteratura italiana 169 (1992): 183-99. Print.

Vendler, Helen. "Shakespeare's Other Sonnets.” In In the Company of Shakespeare: Essays on English Renaissance Literature in Honor of G. Blakemore Evans. Ed. Thomas Moisan and Douglas Bruster. Cranbury NJ: Associated University Presses, 2002. 161-76. Print. 
Vergil. Publi Vergili Maronis Opera (Aeneis pp. 82-338). Ed. J. Conington. New York: Harper and Brothers, 1894. Print.

Walker, Greg. Writing under Tyranny: English Literature and the Henrician Reformation. Oxford: Oxford UP, 2005. Print.

Wallace, David. Chaucerian Polity: Absolutist Lineages and Associational Forms in England and Italy. Stanford: Stanford UP, 1997. Print.

Watson, George. The English Petrarchans: A Critical Bibliography of the Canzoniere. London: Warburg Institute, 1967. Print.

Watson, Thomas. The Hekatompathia or Passionate Centurie of Love. Manchester: Charles S. Simms, 1869-71 (reprint of 1581 edition). Print.

Whittier, Gayle. "The Sonnet" Body and the Body Sonnetized in Romeo and Juliet." Shakespeare Quarterly 40 (1989): 27-41. Print.

Wilkins, E.H. “Cantus Troili.” English Literary History 16 (1949): 167-73. Print.

[Wyatt, Sir Thomas]. Sir Thomas Wyatt, The Complete Poems. Ed. R.A. Rebholz. Harmondsworth, England: Penguin, 1978. Print.

Zitner, S. P. "Truth and Mourning in a Sonnet by Surrey." English Literary History 50 (1983): 509-29. Print. 